\title{
ENHANCED PRODUCTION LEVEL OF QUININE IN CELL SUSPENSION CULTURE OF CINCHONA LEDGERIANA MOENS BY PACLOBUTRAZOL
}

\author{
DIAH RATNADEWI ${ }^{1} *$, DEDI SATRIAWAN ${ }^{2}$, and SUMARYONO ${ }^{3}$ \\ ${ }^{1}$ Department of Biology, Faculty of Mathematics and Natural Sciences, Bogor Agricultural University, \\ Darmaga Campus, Bogor 16680, Indonesia \\ ${ }^{2}$ Department of Biology, Faculty of Mathematics and Natural Sciences, Bengkulu University, Kandang \\ Limun Campus, Bengkulu, Indonesia \\ ${ }^{3}$ Indonesian Biotechnology Research Institute for Estate Crops, \\ Jalan Taman Kencana No. 1, Bogor 16151, Indonesia
}

Received 10 Januari 2013/Accepted 22 May 2013

\begin{abstract}
Quinine is one of the major alkaloids in Cinchona spp., and it is used both as a medication and as a drink additive. The plant produces most of its alkaloids in the bark after 6-8 years of age. Repeated harvests can be performed until the plant dies, but only after every 3-5 years. We tested an improved method for culturing cell suspensions of Cinchona ledgeriana investigate the possibility of increasing production of quinine. The clone QRC 315 was treated with either a growth retardant (abscisic acid or paclobutrazol) or precursor feeding of Ltryptophan. To generate stress, we applied mannitol at $5.3 \mathrm{~g} / \mathrm{L}$ combined with sucrose at a lower concentration $(20 \mathrm{~g} / \mathrm{L})$, and we used sucrose at $30 \mathrm{~g} / \mathrm{L}$ as the control. Paclobutrazol $(7$ $\mathrm{mg} / \mathrm{L})$ significantly suppressed cell growth and produced the highest level of quinine $(11 \%)$ after 7 weeks of culture. L-tryptophan also reduced cell growth, but without any positive effect in the production of quinoline. The highest amount of quinine per culture flask, however, resulted from cells treated with $3 \mathrm{mg} / \mathrm{L}$ abscisic acid.
\end{abstract}

Key words: Cinchona ledgeriana, suspension culture, quinine, paclobutrazol

\section{INTRODUCTION}

More than 30 alkaloids have been isolated from the bark of Cinchona spp. but the most economically important cinchona alkaloids are the quinolines: quinine, quinidine, cinchonine, and cinchonidine (McCalley 2002). Quinine is the major alkaloid and has been used for hundreds of years as an anti-fever agent and for prevention and treatment of malaria. Malaria still exists in many tropical areas of the world. The World Health Organization (2011) reported 36000-655000 deaths

$\overline{\text { *Corresponding author : diahbiologi.ipb@gmail.com }}$ 
between 2009 and 2010 in 106 malaria-endemic countries. Apart from its use to treat malaria, quinine also has analgesic and anti-inflammatory properties; its sulfate salt is used in eye lotions as an antibacterial and anesthetic agent (Taylor 2005, Kurian \& Sankar 2007). South Americans use quinine as a natural remedy for cancer, amoebic infections, heart problems, diarrhea, dysentery, varicose veins, and nocturnal leg cramps (Taylor 2005). In addition, quinine salts are added to tonic drinks and beverages to achieve a bitter taste.

Taylor (2005) reported a commercial market of approximately 300-500 metric tons of quinine alkaloids, which are extracted annually from 5000-10000 metric tons of harvested bark. At the time of that report, half of the harvest was directed to the food industry. The bark of wild Cinchona yields $7 \%$ quinine, whereas cultivated crops yield up to $15 \%$, none of which can be obtained until after the plant is 6-12 years old (Barrett 1928). Quinine production from its cultivation is, therefore restricted by these growth limitations.

Cell suspension culture of Cinchona spp. could solve the above problem. Several groups of researchers have attempted enhancement of cinchona alkaloid production in cell suspension cultures by using stressing agents, precursors, elicitors, auxins, and enzymes (Harkes et al. 1986, Wijnsma et al. 1986, Payne et al. 1987, Robins et al. 1987, Toruan-Mathius et al. 2006). Previous research on C. ledgeriana clone QRC 313 increased quinine content to $0.12 \%$, which was 11 -fold more than that in control cells (Ratnadewi \& Sumaryono 2010). Although promising, this result is still far from satisfactory. In this study, we sought to improve quinine production methods by testing a selected potential clone of C. ledgeriana in treated cell-suspension cultures.

\section{MATERIALS AND METHOD}

\section{Preparation of cell-suspension cultures}

Lamina of young leaves (the second or the third leaf from the shoot tip) from the C. ledgeriana clone QRC 315 were surface-sterilized with $0.2 \%$ Dithane M-45 for 10 minutes, followed by treatment with $20 \%$ commercial $\mathrm{NaOCl}$ for 15 minutes. These lamina were used as explants for callus production on semi-solid Woody Plant (WP) media (Lloyd \& McCown 1981), which contained $15 \mu \mathrm{M}$ picloram, $2 \mu \mathrm{M}$ benzyladenin (BA), $1 \mu \mathrm{M}$ phloroglucinol, and was solidified with $3.5 \mathrm{~g} / \mathrm{L}$ Gelrite (MB Cell). Sucrose, at a standard level $(30 \mathrm{~g} / \mathrm{L})$, was added to the media. After 8 weeks in the initiation and proliferation media, fast-growing calli were transferred to baffle flasks that contained WP liquid media, and homogenized for 1 week before being used for cell suspension culture. Liquid media composition was the same as the semi-solid, except that BA was reduced to $0.5 \mu \mathrm{M}$. This procedure was taken from that described by Sumaryono and Riyadi (2005), with slight modification.

One spatula (0.2-0.3 g) of cells, which had been filtered through 1000 and then $50 \mu \mathrm{m}$ filter mesh, was transferred into Erlenmeyer flasks containing $20 \mathrm{~mL}$ liquid WP media, of which the composition was the same as for cell homogenization. This was designated as the basic media for this research. We varied the basic media by addition of certain growth regulators: either (1) abscisic acid (ABA) or paclobutrazol (PBZ); 
and (2) a precursor, L-tryptophan (Trp), in combination with sucrose (at either a standard or lower concentration) with or without mannitol. We applied the following treatments to the basic media: (1) $1 \mathrm{mg} / \mathrm{L} \mathrm{ABA}+30 \mathrm{~g} / \mathrm{L}$ sucrose(ABA1), $3 \mathrm{mg} / \mathrm{L}$ $\mathrm{ABA}+30 \mathrm{~g} / \mathrm{L}$ sucrose (ABA3), $0.2 \mathrm{mg} / \mathrm{L}$ tryptophan $+20 \mathrm{~g} / \mathrm{L}$ sucrose $+5.3 \mathrm{~g} / \mathrm{L}$ mannitol (Trp0.2-M); (2) $2 \mathrm{mg} / \mathrm{L}$ tryptophan $+20 \mathrm{~g} / \mathrm{L}$ sucrose $+5.3 \mathrm{~g} / \mathrm{L}$ mannitol (Trp2-M); 5 mg/L PBZ + $20 \mathrm{~g} / \mathrm{L}$ sucrose + $5.3 \mathrm{~g} / \mathrm{L}$ mannitol (PBZ5-M); and $7 \mathrm{mg} / \mathrm{L}$ $\mathrm{PBZ}+20 \mathrm{~g} / \mathrm{L}$ sucrose $+5.3 \mathrm{~g} / \mathrm{L}$ mannitol (PBZ7-M). The molarity of $30 \mathrm{~g} / \mathrm{L}$ sucrose was equivalent to that of $20 \mathrm{~g} / \mathrm{L}$ sucrose $+5.3 \mathrm{~g} / \mathrm{L}$ mannitol. The cell suspension cultures were maintained for 7 weeks on a horizontal shaker, at $100 \mathrm{rpm}, 26 \pm 1^{\circ} \mathrm{C}$, under light intensity of $20 \mu \mathrm{mol}$ photon $/ \mathrm{m}^{2} /$ second for 12 hours per day.

Cell growth was measured once per week until the cells were harvested. We used cell volume after sedimentation (CVS) to represent cell growth, according to the methods described by Blom et al. (1992).Cell volume (a mL) was then calibrated into fresh weight $(\mathrm{g})$ using the following formula: $\{(\mathrm{a}$ 0.4565) 0.3252$\}$.

\section{Quinoline extraction and analysis}

At weeks 6 and 7, five flasks of suspension culture were simultaneously harvested from each treatment for quinoline alkaloid content because Cinhona ledgeriana cells achieve their maximum growth at week 6 (Sumaryono \& Riyadi 2005). Reversed-phase high-performance liquid chromatography (HPLC; Varian-USA, type 940) was used to measure the four major quinolines (quinine, quinidine, cinchonine, and cinchonidine).

Quinoline extraction and analysis was performed as described previously by Klink (1979), with some modifications. Briefly, as much as $0.5 \mathrm{~g}$ oven-dried cell powder was taken for the extraction and purification, boiled in $95 \mathrm{~mL}$ aquadest for 25 minutes, and then allowed to cool at room temperature. The remaining liquid was then adjusted to $100 \mathrm{~g}$ by adding aquadest. A 5-mL aliquot was taken from decanted solution and filtered using a $0.45-\mu \mathrm{m}$ millipore filter then injected into an HPLC column (Pursuit XRs $3 \mu \mathrm{C}-18$, column length $150 \mathrm{~cm}$ x $4.6 \mathrm{~mm}$ ). The column temperature was adjusted to $30^{\circ} \mathrm{C}$. Aquadest, acetonitril, and glacial acetic acid (ratio 81:18:1, respectively) served as an eluent using a $0.6 \mathrm{~mL}$ per minute flow rate with six attenuation. Standard quinoline alkaloids (Sigma, Germany) served as positive controls. The chromatogram was detected by UV-Vis at $250 \mathrm{~nm}$. Data from each treatment were collected from duplo analysis.

\section{RESULTS AND DISCUSSION}

\section{Cell growth}

One week after being transferred into treated liquid media, the cells grew well. Treatment with ABA with the normal rate of sucrose $(30 \mathrm{~g} / \mathrm{L})$ demonstrated the highest growth, whereas Trp0.2-M, Trp 2-M, PBZ5-M, and PBZ7-M resulted in lower performance, even compared to the control. PBZ7-M greatly restricted cell growth, whereas PBZ5-M slightly reduced cell growth. In general, the highest fresh weight was reached at the sixth week in the treated media, and it decreased afterwards (Fig. 1-A, 
-B, -C). This was consistent with the results of Sumaryono and Riyadi (2005).

In previous work (Ratnadewi \& Sumaryono 2010), the incorporation of ABA and PBZ into the media at the fifth week of cell culture had no negative effect on cell growth. In this research, ABA treatment from the beginning of the culture even increased growth. ABA can both promote and inhibit plant growth (Finkelstein \& Rock 2002). It has a complex role in various cellular processes, such as embryo maturation and germination, vegetative growth, and tolerant response to drought stress (Xiong \& Zhu 2003 Hirayama \& Shinozaki 2007, Hubbard et al. 2010).
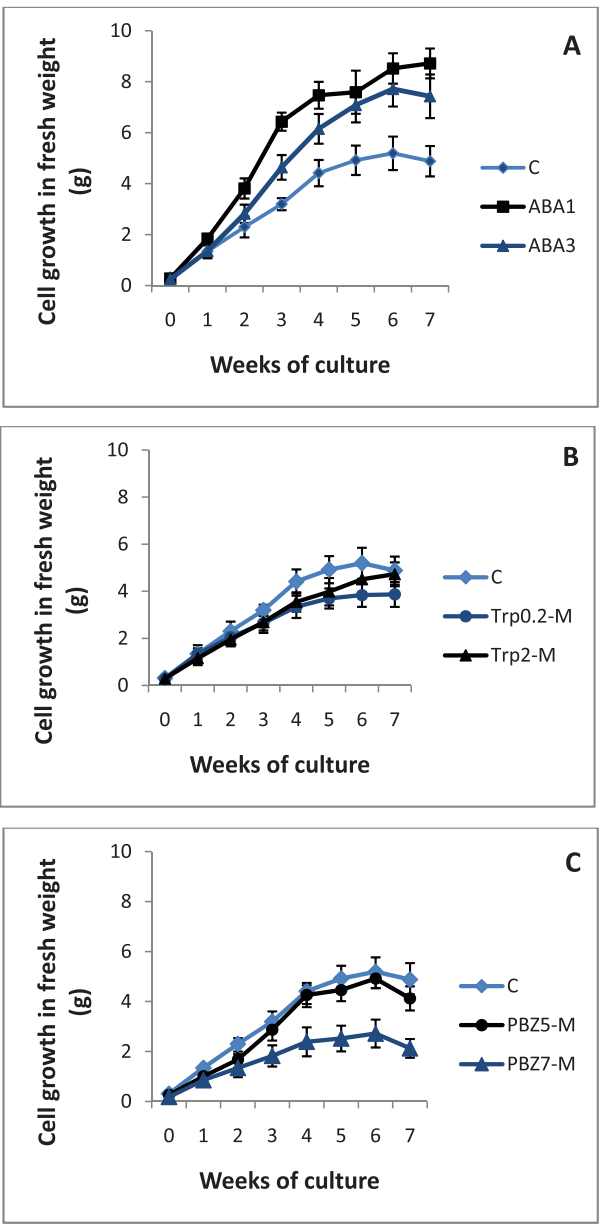

Data are expressed as mean $\pm S D(n=10)$.

C, control media/basic media; ABA1, basic media treated with1 mg/L ABA; ABA3, basic media with $3 \mathrm{mg} / \mathrm{L}$ ABA; $\operatorname{Trp} 0.2-\mathrm{M}$, basic media with $0.2 \mathrm{mg} / \mathrm{L}$ tryptophan $+20 \mathrm{~g} / \mathrm{L}$ sucrose $+5.3 \mathrm{~g} / \mathrm{L}$ mannitol; $\operatorname{Trp} 2-\mathrm{M}$, basic media with $2 \mathrm{mg} / \mathrm{L}$ tryptophan $+20 \mathrm{~g} / \mathrm{L}$ sucrose $+5.3 \mathrm{~g} / \mathrm{L}$ mannitol; PBZ5-M, basic media with $5 \mathrm{mg} / \mathrm{L} \mathrm{PBZ}+$ $20 \mathrm{~g} / \mathrm{L}$ sucrose $+5.3 \mathrm{~g} / \mathrm{L}$ mannitol; PBZ7-M, basic media with $7 \mathrm{mg} / \mathrm{L}$ PBZ $+20 \mathrm{~g} / \mathrm{L}$ sucrose $+5.3 \mathrm{~g} / \mathrm{L}$ mannitol.

Figure 1. Cell growth in suspension culture of C. ledgeriana treated with ABA (A), Tryptophan (B) and PBZ (C). 
In contrast, we observed that growth inhibition of PBZ, applied from the starting point of culture, reduced cell growth. We hypothesized that the inhibiting action of PBZ required more time to cause an effect. By increasing the concentration of PBZ to $7 \mathrm{mg} / \mathrm{L}$, combined with $5.3 \mathrm{~g} / \mathrm{L}$ mannitol and $20 \mathrm{~g} / \mathrm{L}$ sucrose, the cell growth rate diminished significantly (Fig. 1-C). PBZ is known to be an antagonist of gibberellins. It inhibits gibberellin biosynthesis at the point when kaurene is oxidized into kaurenoic acid (Graebe 1987, Chaney 2004), because gibberellin and ABA biosynthesis begin at the same initial pathway (i.e., from geranyl pyrophosphate), both growth regulators may be affected by PBZ along their synthesis pathways. Also, blockage of the terpenoid pathway causes accumulation of ABA (Chaney 2004) and could therefore, lead to unbalanced cellular metabolism. This, in turn, would reduce the rate of cell division (Graebe 1987). Chaney (2004) suggested that these cells will still divide and differentiate at the same rate but simply do not elongate. This may explain why cell growth was lower in the cultures treated with PBZ.

One of the precursors in the biosynthesis of quinoline alkaloids is tryptophan (Facchini 2001). We used it in combination with mannitol as a partial substitute of sucrose in the culture media with the expectation that it would increase the production of quinoline in cells. Tryptophan is also involved in the first step of the auxin biosynthesis pathway. In this study, cell growth rate in tryptophan-treated media, however, was less than that of untreated cells. This may be because tryptophanderived auxin either was not at an optimal level or simply auxin synthesis from tryptophan did not occur.

Sucrose is the main source of energy and carbon in in vitro cultures. Substitution of some sucrose in media with mannitol reduces the supply of carbon and energy to cells because mannitol is an alcohol sugar that cannot replace sucrose (although it determines the osmotic potential value of media). Mannitol has been used as an osmotic stressing agent in many experiments (Hassanein 2004, 2010; Hussein \& Aqlan 2011). Le Clere et al. (2010) confirmed that sugar concentration in in vitro-cultured maize kernels regulates the expression of the gene, $Z m Y U C$, which is involved in the biosynthesis of auxin through hydroxylation of tryptamine. Reduced levels of sucrose in the culture media, along with mannitol substitution, combined with tryptophan, might explain the lower growth rate of the corresponding treated cultures, which may have used less tryptophan for the synthesis of auxin.

\section{Quinine in the suspension cultures}

In normal culture media, Cinchona cells produced quinoline alkaloids as demonstrated by Robins et al. (1986) and Ratnadewi and Sumaryono (2010). Quinine appeared to be the main alkaloid produced by the cells, occurring at levels of $4-7 \%$ in the control media $(\mathrm{C})$.

We found all four alkaloids at the sixth week of culture in all treatments (Table 1). Cinchonidine was the least abundant, followed by cinchonine, quinidine, and quinine, which was the most abundant. This percentage of quinine was further augmented 1 week later, at the seventh week of culture, which was in contrast to our results for quinidine, cinchonine, and cinchonidine. The four types of alkaloid are readily 
Enhanced Production Level of Quinine by Paclobutrazol - Diah Ratnadewi et al.

Table 1. Quinoline content in cells of $C$. ledgeriana at 6 and 7 weeks of culture ( $\%$ dry weight)

\begin{tabular}{ccccccccc}
\hline & \multicolumn{2}{c}{ Quinine } & \multicolumn{2}{c}{ Quinidine } & \multicolumn{2}{c}{ Cinchonine } & \multicolumn{2}{c}{ Cinchonidine } \\
Treatment & 6 weeks & 7 weeks & 6 weeks & 7 weeks & 6 weeks & 7 weeks & 6 weeks & 7 weeks \\
\hline C & 4.60 & 7.12 & 2.61 & 1.40 & 0.69 & 0.42 & 0.40 & 0.18 \\
ABA1 & 3.97 & 5.7 & 2.40 & 2.32 & 0.57 & 0.56 & 0.27 & 0.20 \\
ABA3 & 5.08 & 6.83 & 3.11 & 2.19 & 0.46 & 0.37 & 0.51 & 0.15 \\
Trp0.2-M & 3.72 & 5.12 & 2.45 & 1.48 & 0.80 & 0.49 & 0.29 & 0.22 \\
Trp2-M & 4.36 & 6.04 & 1.97 & 1.26 & 0.62 & 0.50 & 0.32 & 0.34 \\
PBZ5-M & 5.01 & 5.75 & 2.80 & 2.07 & 0.73 & 0.71 & 0.19 & 0.28 \\
PBZ7-M & 4.15 & 10.90 & 3.66 & 2.39 & 2.90 & 0.65 & 0.28 & 0.30 \\
\hline
\end{tabular}

Note :

These data are means of duplo analysis, collected each from 5 flasks of cell culture

transformed from one to another type due to their similar molecular structure (Tadeusz 2007). All the treatments applied to the suspension cultures were best at producing quinine rather than the other types of quinoline. Cell suspension treated with PBZ7-M presented a remarkably high percentage of quinine content (11\%). This value was 1.5-fold higher than that of the untreated cultures at the seventh week. In cells treated with ABA, Trp-M or PBZ5-M, the quinine level was either at an average level or less than that contained in the untreated cells $(\mathrm{C})$.

Precursor feeding of tryptophan did not improve quinoline alkaloid production in Cinchona cell cultures. This is consistent with the results obtained by Robins et al. (1987) in C. pubescens and by Payne et al. (1987) in a transformed line of C.ledgeriana. Harkes et al. (1986) and Robins et al. (1987) found an accumulation of $\beta$-carboline alkaloids and indole-3-aldehyde in tryptophan-fed growth media, with and without Cinchona cells. According to Cao et al. (2007), $\beta$-carboline alkaloids (a large group of indole alkaloids) are easily transformed from tryptophan, tryptamine, pyruvate, or acetate precursors by Pictet-Spengler reactions, even in foods and beverages. This indicates that the transformation of tryptophan to quinoline alkaloids needs more particular conditions in living cells. Moreover, Payne et al. (1987) suggested that growing cultures in darkness is more favorable than under light when attempting to enhance alkaloid accumulation. Ratnadewi and Sumaryono (2010) found that providing $0.2 \mathrm{mg} / \mathrm{L}$ tryptophan to the $C$ ledgeriana clone QRC 313 increased total alkaloids (predominantly cinchonidine) 35fold more than those in untreated cultures after 6 weeks.

Cinchona plants naturally have variable types of alkaloids. According to Taylor (2005), quinine content averages $1-3 \%$ in C. pubescens and 3-13\% in C ledgeriana, whereas $C$. succirubra can reach $4-14 \%$ but only $6-8$ years after planting.

When we examined the dry weight cells collected from each culture flask and the quinine content percentage, we found that cells treated with ABA which had the highest rate of cell growth produced the highest amount of quinine at 6 and 7 weeks of culture at the end, compared to any other treatment (Table 2-A and -B) and ABA3 had the greatest abundance of quinine (almost 3 times more than that produced by PBZ7-M per flask). It remains challenging to improve quinine production in cells treated with PBZ7-M. 
Table 2. Production of quinine per flask of cell culture of C.ledgeriana treated with various

\begin{tabular}{|c|c|c|c|}
\hline Treatment & $\begin{array}{l}\text { Means of cell dry } \\
\text { weight/flask (g)* }\end{array}$ & $\begin{array}{l}\text { Quinine } \\
(\%)^{* *}\end{array}$ & Quinine (mg/flask) \\
\hline $\mathrm{C}$ & $0.122 \pm 0.042$ & 4.6 & 0.561 \\
\hline ABA1 & $0.201 \pm 0.024$ & 3.97 & 0.722 \\
\hline ABA3 & $0.182 \pm 0.046$ & 5.08 & 1.021 \\
\hline Trp0,2-M & $0.091 \pm 0.018$ & 3.72 & 0.338 \\
\hline Trp2-M & $0.106 \pm 0.032$ & 4.36 & 0.462 \\
\hline PBZ5-M & $0.116 \pm 0.078$ & 5.01 & 0.581 \\
\hline PBZ7-M & $0.064 \pm 0.041$ & 4.15 & 0.265 \\
\hline Treatment & $\begin{array}{l}\text { Mean of cell dry } \\
\text { weight/flask }(\mathrm{g}) *\end{array}$ & $\begin{array}{l}\text { Quinine } \\
\qquad(\%) * *\end{array}$ & $\begin{array}{l}\text { Quinine } \\
\text { (mg/flask) }\end{array}$ \\
\hline C & $0.115 \pm 0.045$ & 7.12 & 0.819 \\
\hline ABA1 & $0.175 \pm 0.032$ & 5.70 & 0.997 \\
\hline ABA3 & $0.206 \pm 0.043$ & 6.83 & 1.407 \\
\hline $\operatorname{Trp} 0,2-\mathrm{M}$ & $0.091 \pm 0.023$ & 5.12 & 0.466 \\
\hline Trp2-M & $0.111 \pm 0.030$ & 6.04 & 0.670 \\
\hline PBZ5 -M & $0.097 \pm 0.064$ & 5.75 & 0.558 \\
\hline PBZ7 -M & $0.050 \pm 0.037$ & 10.90 & 0.545 \\
\hline
\end{tabular}

\section{CONCLUSIONS}

The growth retardant paclobutrazol at $7 \mathrm{mg} / \mathrm{L}$ combined with $5.3 \mathrm{mg} / \mathrm{L}$ mannitol and a lower concentration of sucrose $(20 \mathrm{mg} / \mathrm{L})$ significantly increased the accumulation of quinine in the cells of C. ledgeriana clone QRC 315. Quinine approached the level extracted from productive $C$. ledgeriana bark.

Precursor feeding by L-tryptophan to the cell culture media increased neither quinine nor the other major quinoline alkaloids. The way in which it transforms to quinoline alkaloids remains incompletely understood.

The high growth rate of cells treated with $3 \mathrm{mg} / \mathrm{L} \mathrm{ABA}$ and sucrose at normal concentration $(30 \mathrm{~g} / \mathrm{L})$ resulted in the most abundance of quinine per culture flask.

\section{ACKNOWLEDGMENTS}

The authors thank the IAARD of the Indonesian Ministry of Agriculture for sponsoring this research through the Incentive Program. 


\section{REFERENCES}

Barrett. 1928. The Tropical Crops. New York: The McMillan.

Blom TJM, Kreis W, Van Iren F, Libbenga KR. 1992. A non-invasive method for the routine-estimation of fresh weight of cells grown in batch suspension cultures. Plant Cell Rep 11:146-9.

Cao R, Peng W, Wang Z, Xu A. 2007. $\beta$-carboline alkaloids: biochemical and pharmacological functions. Curr Med Chem14: 479-500.

Chaney WR. 2004. Paclobutrazol: more than just a growth retardant. Pro-Hort Conf. Peoria IL: Febr 4th. Department of Forestry and Nat Res, Purdue University.www.ina online.org/prohort/TreeGrowth. pdf.

Facchini PJ. 2001. Alkaloid biosynthesis in plants: Biochemistry, cell biology, molecular regulation and metabolic engineering applications. Ann Rev Plant Physiol Plant Mol Biol 52:29-66.

Finkelstein RR, Rock CD. 2002. Abscisic biosynthesis and response. In: The Arabidopsis Book. New York. Amer Soc Plant Biologists1-52.

Graebe JE. 1987. Gibberellin biosynthesis and control. Annu Rev in Plant Physiol 38: 419-65.

Harkes PAA, De Jong PJ, Wijnsma R, Verpoorte R, Van der Leer. 1986. The influence of production media on cinchona cell cultures; spontaneous formation of $\beta$-carbolines from L-tryptophan. Plant Sci 47:71-6.

Hassanein AM. 2004. Effect of relatively high concentration of mannitol and sodium chloride on regeneration and gene expression of stress tolerant (Alhagi graecorum) and stress sensitive (Lycopersicon esculentum $\mathrm{L}$ ) plant species. Bulg J Plant Physiol 30: 19-36.

Hassanein AM. 2010. Establishment of efficient in vitro method for drought tolerance evaluation in Pelargonium. J Hort Sci \& Ornament Plant 2: 8-15.

Hirayama T, Shinozaki K. 2007. Perception and transduction of abscisic acid signals: keys function of the versatile plant hormone ABA. Trends in Plant Sci 12:343-51.

Hubbard KE, Nishimura N, Hitomi K, Getzoff ED, Schroeder JI. 2010. Early abscisic acid signal transduction mechanisms: newly discovered components and newly emerging questions. Gene Develop 24:1695708.

Hussein EA, Aqlan EM. 2011. Effect of mannitol and sodium chloride on some total secondary metabolites of fenugreek calli cultured in vitro. Plant Tiss Cult Biotech 21:35-43.

Klink F. 1979. Determination of caffeine and theobromine in chocolate product. In: Varian Instrument at Work. Walnut Creek 94-7.

Kurian A, Sankar MA. 2007. Medicinal plants. In: Horticultural Science Series-2. Edited by Peter KV. New DelhiIndia: New India Publ Agency.

Le Clere S, Schmelz EA, Chourey PS. 2010. Sugar levels regulate tryptophan-dependent auxin biosynthesis in developing maize kernels. Plant Physiol 153: 306-18.

Lloyd G, McCown B. 1981. Commercially feasible micropropagation of mountain laurel Kalmia latifolia by use of shoot tip culture. Comb Proc Intl Plant Prop Soc 30: 421-27.

McCalleyDV. 2002. Analysis of the cinchona alkaloids by high-performance liquid chromatography and other separation techniques. J Chromatogr A 967:1-19.

Payne J, Rhodes MJ, Robins RJ. 1987. Quinoline alkaloid production by transformed cultures of Cinchona ledgeriana. Planta Med 53:367-72.

Ratnadewi D, Sumaryono. 2010. Quinoline alkaloids in suspension cultures of Cinchona ledgeriana treated with various substances. Hayati J Biosci 17: 179-82.

Robins RJ, Hanley AB, Richards SR, Fenwick GR, Rhodes MJC. 1987. Uncharacteristic alkaloid synthesis by suspension cultures of Cinchona pubescens fed with L-tryptophan. Plant Cell, Tiss Organ Cult 9: 49-59.

Sumaryono, Riyadi I. 2005. Growth of callus and cell suspension cultures of cinchona (Cinchona ledgeriana Moens). Menara Perkebunan 73:1-9. 
Tadeusz A. 2007. Alkaloid-secrets of life.In Alkaloid Chemistry, Biological Significance, Applications and Ecological Role. Elsevier.

Taylor L. 2012. The healing power of rainforest herbs. [Tropical Plant Database: File for Quinine

(Cinchona officinalis). Rainforest database.com/plants/quinine.htm. 2005]. Cited 13 August 2012.

Toruan-Mathius N, Haris N, Santoso J, Ade-Heri. 2006. Effect of elicitation on growth and alkaloid quinoline production in hairy root of cinchona plant (Cinchona succirubra Pavon ex Klotzsch). Menara Perkebunan 74:10-22.

Wijnsma R, Verpoorte R, Harkes PAA, van Vliet TB, Ten Hoopen HJG, Svendsen AB. 1986. The influence of initial sucrose and nitrate concentration on the growth of Cinchona ledgeriana cell suspension cultures and the production of alkaloids and anthraquinones. Plant Cell Tiss Org Cult 7:21-9.

World Health Organization: World Malaria Report. [http://www.who.int/malaria/world_malaria_report2011/en/2011]. Cited 26 August 2012.

Xiong L, Zhu J-K. 2003. Regulation of abscisic acid biosynthesis. Plant Physiol 133: 29-36. 